Ekuitas: Jurnal Pendidikan Ekonomi

Volume 7, Number 1, 2019, pp. 1 - 4.

P-ISSN : 2354-6107 E-ISSN : 2549-2292

Open Access: https://ejournal.undiksha.ac.id/index.php/EKU

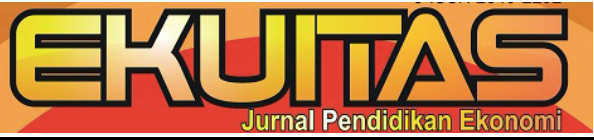

\title{
Penerapan Sistem Informasi Raport Online
}

\author{
Putu Ayu Desy Pangastuti ${ }^{*}$, Denies Priantinah ${ }^{2}$ \\ 1,2, Universitas Negeri Yogyakarta, Yogyakarta - Indonesia
}

\author{
A R T I C L E I N F O \\ Article history: \\ Received 2 january 2019 \\ Received in revised form \\ 13 may 2019 \\ Accepted 06 june 2019 \\ Available online 15 june \\ 2019 \\ Kata Kunci: \\ system informasi, raport \\ online. \\ Keywords: \\ information system, online \\ report card.
}

\begin{abstract}
A B S T R A K
Kemajuan teknologi memberikan kemudahan bagi setiap orang berkaitan dengan kemudahan dalam mendapatkan dan mengeloloa informasi. Salah satu contoh nyata adalah perkemabangan internet yang menjadi ikon perkembangan teknologi. Khususnya pada era pendidikan 4.0 internet sangat berperan penting dalam proses pendidikan. Pada era pendidikan 4.0 pendidik maupun peserta didik di tuntut untuk dapat mengintegrasikan teknologi dalam setiap kegiatan pendidikan. Salah satu penerapan teknologi dalam pendidikan saat ini adalah dengan adanya system informasi nilai raport yang berbasis pada internet atau yang biasa kita kenal dengan rapot online. Penelitian ini merupakan studi pustaka yang bertujuan untuk mengumpulkan informasi yang berkaitan dengan penggunaan system informasi raport online yang diterapkan oleh beberapa sekolah. hasil yang diperoleh dari studi pustaka ini adalah system raport online memberikan kemudahan bagi pendidik untuk melakukan pengolahan data nilai peserta didik yang dapat diakses baik oleh peserta didik maupun orang tua.
\end{abstract}

A B S T R A C T

Technological advancements make it easy for everyone related to the ease of getting and managing information. One concrete example is the development of the internet which has become an icon of technological development. Especially in the era of education 4.0, internet plays a very important role in the education process. In the education era 4.0 educators and students are required to be able to integrate technology in every educational activity. One application of technology in education today is the existence of a system of information on report cards based on the internet or what we are familiar with online report cards. This research is a literature study that aims to collect information relating to the use of online report card information systems that are applied by several schools. The results obtained from this literature study are online report cards that make it easy for educators to process student value data that can be accessed by both students and parents.

Copyright (C) Ekuitas: Jurnal Pendidikan Ekonomi. All rights reserved.

\footnotetext{
* Corresponding author.

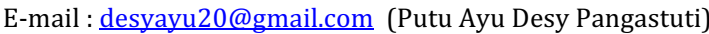




\section{Pendahuluan}

Perkembangan teknologi yang semakin pesat mengakibatkan sarana dan prasarana dalam pendidikan turut serta mengalami perkembangan. Khususnya di era pedidikan 4.0 segala kegiatan pendidikan telah terkomputerisasi dengan bantuan internet. Dengan internet akses atas informasi yang dibutuhkan pendidik maupun peserta didik dapat di lakukan dengan berbagai perangkat elektronik dengan mudah. Salah satu akses informasi yang dibutuhkan oleh pendidik maupun peserta didik adalah pengolahan nilai di sekolah.

Pengolahan nilai siswa merupakan salah satu bagian dari kegiatan belajar mengajar (KBM) di sekolah. Yang sangat berperan penting dalam belajar mengajar yangmerupakan alat ukur prestasi siswa. Dengan adanya pengolahan dan manajemen yang baik pengolahan data nilai akan lebih mudah cepat, akurat. Pengolahan yang selama ini dilakukan manual dapat diatasi dengan adanya system yang dapat membantu memperlancar proses pengolahan nilai siswa. Berdasarkan alsan diatas maka penggunaan system informasi raport online dipandang perlu untuk di terapkan pada setiap sekolah.

\section{Landasan Teori}

\section{Konsep Sistem}

Dalam mendefinisikan system terdapat dua kelompok pendekatan yang dapat digunakan, yakni pendekatan yang menekankan pada prosedurnya dan yang menekankan pada komponen atau elemennya. Dilihat dari prosedur maka system di definisikan sebagi suatu jaringan kerja prosedurprosedur yang saling berhubungan berkumpul bersama-sama untuk melakukan suatu kegiatan atau untuk menyelesaikan suatu sasaran tertentu.

Pendekatan system yang menekankan pada elemen atau komponen mendefinisikan system sebagai kumpulan elemen yang berinteraksi untuk mencapai suatu tujuan tertentu. Kedua kelompok definisi ini adalah benar dan tidak bertentangan. Yang berbeda adalah cara pendekatannya.

\section{Definisi Sistem}

Secara sederhana system dapat diartikan sebagi suatu kesatuan atau kumpulan dari unsur maupun variabel yang saling terorganisasai, berinteraksi dan bergantung satu sama lainnya. Menurut Mundik dan Ros sebuah system merupakan seperangkat elemen yang digabungkan satu dengan yang lainnya untuk tujuan bersama. Sedangkan kamus webster's Unbriged mengatakan system adalah elemen-elemen yang saling berhubungan dan membentuk satu kesatuan organisasi (Fatta, 2007). Sistem sebagai sekelompuk elemen - elemen yang berinteraksi dengan maksut yang sama untuk mencapai suatu tujuan. Sumber daya mengalir dari elemen output dan untuk menjamin prosesnya berjalan dengan baik maka dihubungkan dengan mekanisme control (Raymond, 1995).

\section{Komponen Dasar Informasi}

Informasi adalah data yang diolah menjadi bentuk yang lebih berguna lebih berarti bagi yang menerimanya. Menurut Brunch dan Gary Grundnifshi mendefinisikan bahwa informasi adalah data yang diletakkan dalam konteks yang lebih berarti dan berguna yang dikomunikasikan kepada penerima untuk digunakan dalam pengambilan keputusan.

Sistem informasi adalah suatu sistem didalam suatu organisasi yang mempertemukan kebutuhan pengolahan transaksi harian, mendukung operasi, bersifat manajerial dan kegiatan strategi dari suatu organisasi dan menyediakan pihak luar tertentu dengan laporan - laporan yang diperlakukan (Jogiyanto, 2005).

\section{Konsep Dasar Pengolahan Nilai Raport}

Nilai adalah rujukan dan keyakinan dalam menentukan pilihan. Selain itu nilai dapat diartikan sebagai patokan normative yang mempengarui manusia dalam menentukan pilihan ddiantaranya cara-cara tindakan alternative. Nilai sama dengan sesuatu yang menyenangkan kita, nilai identic dengan apa yang di inginkan, nilai merupakan sarana pelatihan kita . Nilai juga diartikan dalam kamus besar Bahasa Indonesia, nilai diartikan sebagai harga, dalam hal ini adalah suatu angka kepandaian.

Raport atau raport adalah buku yang berisi nilai kepandaian dan prestasi belajar murid di sekolah, berfungsi sebagai laporan resmi guru kepada orangtua wali murid yang wajib menerimanya. Raport itu sendiri merupakan salah satu pertanggung jawaban sekolah terhadap masyarakat tentang kemampuan yang dimiliki siswa yang berupa sekumpulan hasil penilaian. 


\section{Metode}

Penelitian ini merupakan penelitian studi pustaka. Data yang digunakan merupakan artikel yang memuat penerapan rapot online di sekolah. Data diolah dengan deskripsi dan simpulan akan dibuat dengan memberikan ulasan atas artikel sumber referensi.

\section{Hasil dan pembahasan}

Wardani (2013) melakukan penelitian pengembangan system informasi pengolahan data nilai siswa berbasis WEB pada sekolah menengah atas. Pada penelitian ini dilakukan pembangunan dan pengimplementasian system pengolahan nilain siswa atau yang sering kita kena dengan raport dengan media HTML atau web. Hasil yang ditemukan menunjukan:

1. System raport online ini dapat menyajikan informasi pengolahan nilai yang akurat dan relevan.

2. Waktu pencatatan nilai dalam raport dapat di hemat dan terdapat kemudahan dalam menginformasikan nilai serta presensi siswa .

3. Hasil laporan nilai masing-masing anak sertapresensi di setiap bulan dapat diperoleh dengan mudah dan tepat waktu.

4. Data yang sedang diproses maupun yang telah lama di evaluasi dapat ditinjau langsung dari computer maupun dari print out.

5. Tampilan nilai sama dengan raport biasanya sehingga mudah dipahami.

Pada tahun 2013, Putri melakukan penelitian Sistem Informasi Pengolahan Nilai Raport Pada Siswa SMP Negeri 1 Yogyakarta. Penelitian ini bertujuan untuk mengembangkan system informasi yang dapat memfasilitasi pengecekan nilai, penyimpanan dan pelaporan nilai siswa secara terkomputerisasi. Sebagai tambahan data berbasis Web ini dapat diakses kapanpun dan dimanapun. Hasil penelitian menunjukkan bahwa:

1. Dengan menggunakan website raport ini siswa dapat memeprmudah siswa dan wali murid untuk melihat data nilai tanpa adanya batasan waktu.

2. Dengan adanya aplikasi ini maka keseluruhan proses input data nilai dapat lebih efektif dan efisien.

3. Cakupan system ini adalah data nilai, wali murid dan guru.

4. Dengan system ini yang dapat melakukan login akses untuk input nilai hanya guru, sedangkan siswa dan wali murid hanya dapat melihat data yang telah di input dikarenakn pengolahan raport ini menggunakan admin login sebagai hak akses.

Fransiska (2015) mengembangkan system informasi pengolahan raport di SMPK ST. ANTONIUS berbasis web. Penelitian ini membahas tentang system pengolahan raport yang diterapakn di SMPK St. Antonius Kalipare. Dimana system lama dinilai kurang efektif karena untuk menghasilkan nilai raport, wali kelas membutuhkan data nilai siswa dari semua guru mata pelajaran untuk dimasukkan kedalam buku jurnal untuk kemudian diamsukkan kedalam raport. Pada proses pengolahan nilai raport sering terjadi kesalahan dan keterlambatan. Wali murid hanya dapat melihat nilai raport pada akhir semester. Dari hasil yang diperoleh ditemukan bahwa system ini dapat memberikan pelayanan kepada wali murid untuk melihat raport anak secara online. Selain itu guru juga dimudahkan untuk mengelola raport dengan cepat sehingga dapat dijadikan alat komunikasi anatara guru, murid beserta wali murid.

Budiyarto (2016) berpendapat bahwa Penggunaan teknologi informasi dalam suatu bidang pendidikan seperti sekolah sangat dibutuhkan untuk mengelola dan menyajikan suatu informasi, diantaranya berupa laporan nilai rapot siswa. Laporan nilai rapot siswa yang terkomputerisasi dapat meminimalisir kesalahan pengelolaan data. Namun dalam kenyataannya, masih ada sekolah yang menyajikan suatu laporan nilai rapot siswa secara tertulis sehingga membutuhkan banyak waktu untuk proses pengelolaannya.

Dengan menerapkan sistem online pada proses pengelolaan nilai dapat mempermudah untuk membuat laporan nilai rapot. Untuk itu dibangunlah sebuah sistem informasi raport online pada SMA Negeri 1 Krembung sehingga dapat mempercepat pengelolaan data nilai siswa pada SMA Negeri 1 Krembung dan menghasilkan suatu laporan nilai rapot siswa. Dengan adanya sistem informasi ini, guru mata pelajaran dan walikelas dapat melakukan pengelolaan nilai siswa dengan mudah dan menghasilkan laporan nilai rapot siswa yang dapat digunakan untuk memberikan informasi ke siswa dan orang tua secara langsung. Selain itu, sistem informasi rapot online SMA Negeri Krembung ini diharapkan mampu membawa dampat positif bagi dunia pendidikan terutama di SMA Negeri 1 
Krembung dalam pekembangan teknologi informasi yang di terapkan di dalam dunia pendidikan, sehingga manfaat positif akan didapatkan

Latumeten (2017) melakukan penelitian pada SD Masehi Pekalongan untuk merancang dan mengimplementasikan raport online. Penelitian ini melaui lima tahapan yakni identifikasi masalah, pengumpulan data, perancangan sistem, pengujian system dan penulisan laporan. Raport disisni ditampilkan melalui website dengan menggunakan PHP Framework Codeigneiter untuk menghasilkan prototype dan merancang database sebagai penyimpanan data dengan menggunakan MySQL. Hasil yang diperoleh berupa system dengan implementasi menggunakan browser. Semua user dapata mengakses melalui website. Aplikasi website raport online ini berguna untuk membantu para murid dan orang tua sebagai media informasi agar dapat membantu perkembangan prestasi anak dikarena mudah untuk diakses oleh semua pihak tanpa perlu menunggu akhir semester.

\section{Simpulan}

Dari pemaparan diatas dapat disimpulkan bawa penerapan system informasi raport online dapat memberikan keuntungan bagi guru, siswa dan wali siswa. Untuk guru waktu input nilai dapat menjadi lebih efisien dikarenakan guru tidak perlu untuk mengumpulkan nilai dari seluruh guru mata pelajaran. Sedangkan untuk siswa dan wali siswa dapat mengakses informasi nilai di setiap waktu tanpa harus menunggu akhir semester.

\section{Daftar Rujukan}

Al Fatta, H. (2007). Analisis \& Perancangan Sistem Informasi; untuk Keunggulan.

BUDIYARTO, N. (2016). Sistem Informasi Raport Online SMA Negeri 1 Krembung. Jurnal Manajemen Informatika, 6(1).

Fransiska, F. L. P. W., \& Nugraha, D. A. (2015). SISTEM INFORMASI PENGOLAHAN RAPORT DI SMPK ST. ANTONIUS KALIPARE BERBASIS WEB. Jurnal Mahasiswa Fakultas Sains dan Teknologi.

Indonesia, K. B. B. (2011). Jakarta. Republik Indonesia.

Jogiyanto, H. M. Analisis \& Desain Sistem Informasi: Pendekatan Terstruktur Teori dan Praktik Aplikasi Bisnis, 2005. Andi Offset, Yogyakarta.

Latumeten, R. K. I. (2017). Perancangan dan Implementasi Raport Online: Studi Kasus SD Masehi Pekalongan (Doctoral dissertation, Program Studi Teknik Informatika FTI-UKSW).

McLeod Jr, R. (1995). Sistem Informasi Manajemen, Studi Sistem Berbasis Komputer. Edisi Bahasa Indonesia. Penerbit PT prenhalindo. Jakarta.

Putri, N. A. A., \& Hartanto, A. D. (2013). Sistem Informasi Pengolahan Nilai Raport Pada Siswa SMP Negeri 1 YOGYAKARTA Berbasis Web. Data Manajemen dan Teknologi Informasi (DASI), 14(3), 38.

Wardani, S. K. (2013). Sistem Informasi Pengolahan Data Nilai Siswa Berbasis Web Pada Sekolah Menengah Atas (SMA) Muhammadiyah Pacitan. IJNS-Indonesian Journal on Networking and Security, 2(2). 